\title{
A long-term study of population dynamics of tardigrades in the moss Rhytidiadelphus squarrosus (Hedw.) Warnst
}

\author{
Rolf SCHUSTER ${ }^{1)}$ and Hartmut GREVEN* \\ Institut für Zoomorphologie und Zellbiologie der Universität Düsseldorf, Universitätsstr. 1, D-40225 Düsseldorf, Germany \\ ${ }^{1)}$ Schule Birklehof 11, D-79856 Hinterzarten, Germany \\ *e-mail corresponding author: grevenh@uni-duesseldorf.de
}

\begin{abstract}
Variation of abundance, dominance and diversity of tardigrades were studied over a period of 54 months in a carpet of the moss Rhytidiadelphus squarrosus that covered a lawn in the Black Forest (Germany). Altogether 19,909 individuals belonging to 24 species were extracted from the moss. Macrobiotus hufelandi (56\%), Macrobiotus richtersi (18\%) and Diphascon pingue (12\%) were the most abundant and dominant species. Dominances of the other species varied between 0.01 to 2.15\%. Generally, species diversity (Shannon-Index and evenness) was highest during the winter. A temporal variation in numbers with a decline in winter and an increase in spring until fall was seen in M. hufelandi, D. pingue and less clear in M. richtersi. Three species (Diphascon rugosum, Hypsibius dujardini, Hypsibius $c f r$. convergens) showed a cyclic variation with clear peaks in wintertime. The moist season favoured species that were considered as hygrophilous in the literature, whereas the relatively dry sunny seasons promoted the relative increase of euryhygric species. The composition of the tardigrade community was strikingly robust over the years. Fourteen species were always present during the entire period of investigation. However, changes in the species composition over the years, and cyclical temporal presence of certain species stress the significance of long-term studies to estimate species richness in a given habitat. Application of the Spearman rank correlation test to the data set of the whole study period showed different correlations between the mean number of tardigrades as well as the mean number of individuals of selected species (dominance >1) and rainfall, humidity and temperature. Correlations confirmed some of the ecological dependences of tardigrade species known from literature. Conflicting classifications suggest dependence from other variables or perhaps presence of ecotypes.
\end{abstract}

Key words: Tardigrada, abundance, dominance, diversity, moss, temperature, rainfall, cyclic fluctuation

\section{INTRODUCTION}

Terrestrial tardigrades are found in various environments, from which mosses appear to be one of the most favourable habitats. Here they may occur abundantly and often with a considerable number of species (Marcus 1929; Morgan 1977; Greven 1980; Ramazzotti \& Maucci 1983; Schuster 2003). However, the processes determining abundances, temporal variation, and species diversity of tardigrades in mosses are not well understood. A variety of abiotic "gross" factors is discussed or has been demonstrated affecting tardigrade populations such as temperature, rainfall, humidity, slope, exposure, type of bedrock, air pollution, altitude, etc. In addition, the species of mosses and factors of these microhabitats such as growth form, rates of desiccation, and $\mathrm{pH}$-values are of considerable significance (Franceschi et al. 1963; Fleeger \& Hummon 1975; Nelson 1975; Morgan 1977; Hallas 1978; Dastych 1987, 1988; Hofmann 1987; Wright 1991; Steiner 1994; Grabowski 1995; Guidetti et al. 1999).

Articles about quantitative variations in populations and communities of tardigrades in mosses of a given site are scarce and rarely cover a sampling period more than one year. Among them a few attempted to correlate number of tardigrades with the regional climate (=mesoclimate). For example, the abundance of Hypsibius convergens was studied over 11 and 12 months (Marcus 1927); Macrobiotus hufelandi and Pseudechinicus pseudocoronifer Ramazzotti, 1983 over 4 months (Franceschi et al. 1963); Macrobiotus hufelandi and Echinicus testudo (Doyère, 1840) over 28 months (Morgan 1977); several species were studied over 21 months by Jennings (1979), and several species over 5 months by Grabowski (1995).

In the present article we examined population dynamics of a tardigrade community in the moss Rhytidiadelphus squarrosus (Hedwig) Warnstorf, 1906 over a period of more than 4 years and correlated the mean number of certain species with temperature, rainfall, and humidity. The study is part of a wider project on the population biology (abundance, age distribution, sex ratio, annidation) of tardigrades in mosses of genus Rhytidiadelphus.

\section{METHODS}

The study site, a lawn of approximately $14 \mathrm{~m}^{2}$, was located on the north side of the Schule Birklehof, Hinterzarten, Black Forest, Germany (47.9 N, 8.1 E; $880 \mathrm{~m}$ above sea level). The type of bedrock was gneiss 


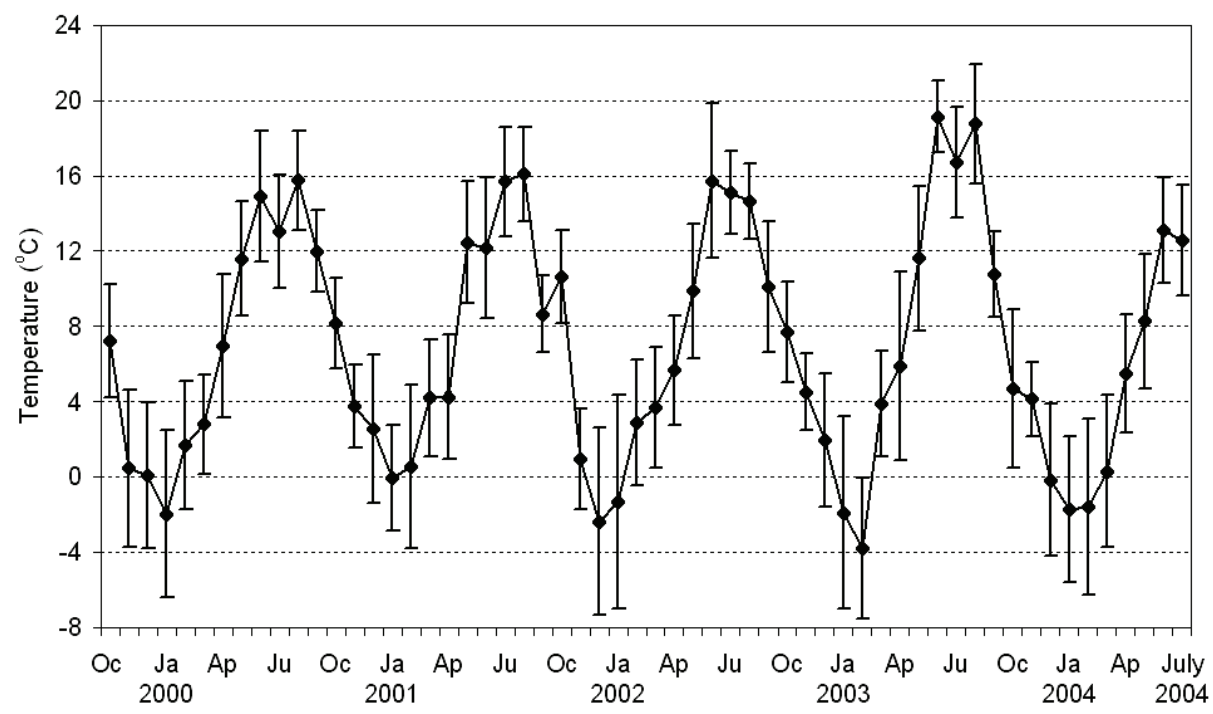

Fig. 1. Monthly mean temperature plus standard deviation from October 1999 to July $2004(n=58)$.

that does not contain carbonate and there was considerable acidification of the soil; the $\mathrm{pH}$ within the moss was $<5$ (Schuster 2003).

The lawn was nearly completely covered by the acidophilous moss Rhytidiadelphus squarrosus rising 3$4 \mathrm{~cm}$ above the ground. Herb and grass species were present in small numbers. Depending on the seasons we recorded Taraxacum officinale Weber, 1780; Veronica chamaedrys Linné, 1753; Ajuga reptans Linné, 1753; Plantago lanceolata Linné, 1753; Stellaria graminea Linné, 1753; Ranunculus repens Linné, 1753; Bellis perennis Linné, 1753; Alchemilla monticola Opiz, 1838; Dactylus glomerata Linné, 1753; Trifolium pratense Linné 1753; Hypochoeris radicata Linné, 1753; and Leontodon autumnalis Linné, 1753.

Single plants of the moss measured $6-10 \mathrm{~cm}$ in length. In the current study we did not distinguish the a-, b-, and c-layer (Overgaard 1948; Hallas 1978; Wright 1991), but samples always contained the c-layer, which was small at our study site and contained only few soil particles.

The site was protected from wind by a hedge (Carpinus betulus Linné, 1753) bordering the north and the west side and by a house wall on the east side. A larch (Larix kaempferi (Lambert) Carriere, 1856) in the middle of the southern border shaded the study site for some hours per day, but the area was sunlit from 11:00 to 16:00 during most of the year. Needles, twigs and branches of the larch were removed in spring every year; the meadow was mowed five times a year (May to October with the exception of August). The lawnmower was adjusted at a level not damaging the mosslayer, but cutting sparse grass and herbs growing between the moss carpets.

From October 1999 to July 2004 six moss samples of $1.8 \mathrm{~cm}^{2}$, one per sector, were cored fortnightly (except August; total number of sampling dates was
108). Each sector was approximately $2.3 \mathrm{~m}^{2}$. In total 648 samples were taken. Samples were examined for tardigrades within 36 hours by soaking them in tap water. Tardigrades were collected using a pipette and a stereoscope and identified according to Ramazzotti \& Maucci (1983) and Dastych (1988) and, if necessary, according to the original description. For the Macrobiotus hufelandi group, we consulted the key published by Bertolani \& Rebecchi (1993) and for the Diphascon pingue group, measurements were based on those of Pilato \& Binda (1997, 1999).

Mesoclimatic data (temperature, rainfall and atmospheric humidity) from October 1999 to July 2004 were obtained from the climatic station "Hinterzarten" (Deutscher Wetterdienst) $2 \mathrm{~km}$ from the site of investigation. Three values per day were averaged monthly (temperature, humidity) or summed up (rainfall) including August, resulting in 58 values. The biotic and abiotic parameters recorded were calculated fortnightly $(\mathrm{n}=108)$, for clarity in some cases, however, monthly $(n=54)$ (for details see the legends). Linear regression was used to show increase or decline of populations and the Spearman rank correlation test to exhibit relationships of mesoclimatic data to abundance of tardigrades (Backhaus et al. 1966). Analyses were performed using WINSTAT (R. Fitch Software D79189, Bad Krozingen).

\section{RESULTS}

\subsection{Temperature, rainfall, and humidity}

Monthly mean temperature, rainfall, and atmospheric humidity during the investigation period are shown in figures 1 and 2. There were heavy frosts in January 2002, in winter 2003 and 2004, with warmer summers in 2002 and 2003 (Fig. 1) exceeding the mean for many years (not pictured). Temperatures below the freezing point were to some extent buffered by snow 


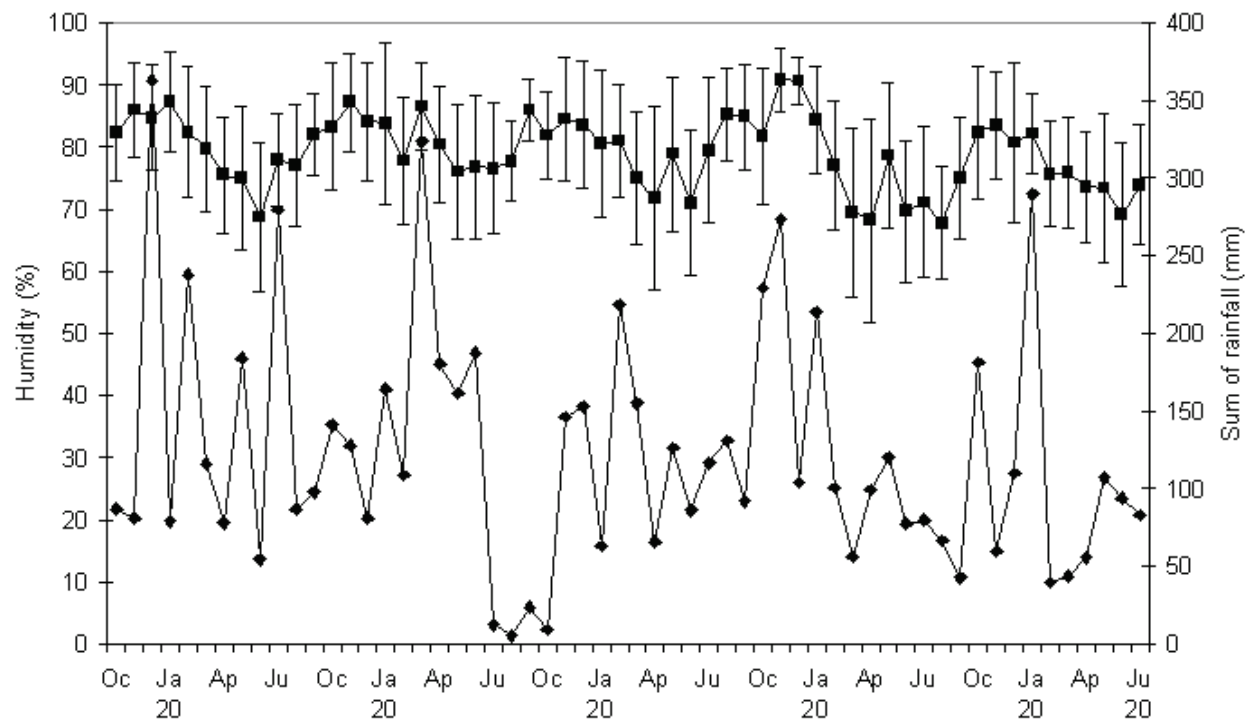

Fig. 2. Monthly summed up rainfall (rhombi) and atmospheric humidity (black squares) plus standard deviation from October 1999 to July $2004(\mathrm{n}=58)$.

Tab. 1. Total number of individuals, exuviae with eggs, eggs, dominances, and frequencies for each tardigrade species collected within the investigation period. Asterisks indicate species found in each year at least once.

\begin{tabular}{|c|c|c|c|c|}
\hline Species & N. individuals & Eggs / Exuviae & Dominance (\%) & Frequency $(\%)$ \\
\hline *Macrobiotus hufelandi Schultze, 1833 & 11118 & 448 & 55.84 & 100 \\
\hline *Macrobiotus richtersi Murray, 1911 & 3600 & 179 & 18.08 & 100 \\
\hline *Diphascon pingue (Marcus, 1936) & 2359 & 170 & 11.85 & 100 \\
\hline *Hypsibius scabropygus Cuénot, 1929 & 429 & 15 & 2.15 & 78.5 \\
\hline *Macrobiotus patiens Pilato et al., 2000 & 403 & 7 & 2.02 & 87.9 \\
\hline *Hypsibius dujardini (Doyère, 1840) & 390 & 58 & 1.96 & 72.9 \\
\hline *Diphascon rugosum Bartos, 1935 & 348 & 22 & 1.75 & 48.6 \\
\hline *Isohypsibius prosostomus (Thulin, 1928) & 294 & 29 & 1.48 & 67.3 \\
\hline *Hypsibius convergens Urbanowicz, 1925 & 246 & 18 & 1.24 & 46.7 \\
\hline *Hypsibius pallidus Thulin, 1911 & 246 & 13 & 1.24 & 65.4 \\
\hline *Hypsibius cfr. convergens & 164 & 8 & 0.82 & 31.8 \\
\hline *Milnesium tardigradum Doyère, 1840 & 101 & 4 & 0.51 & 48.6 \\
\hline *Diphascon oculatum Murray, 1906 & 77 & 0 & 0.39 & 41.1 \\
\hline *Diphascon prorsirostre Thulin, 1928 & 63 & 1 & 0.32 & 39.3 \\
\hline Isohypsibius pappi (Iharos, 1966) & 24 & 7 & 0.12 & 16.8 \\
\hline Hypsibius sp. & 12 & 0 & 0.06 & 2.8 \\
\hline Diphascon nobilei Binda, 1969 & 8 & 0 & 0.04 & 2.8 \\
\hline Minibiotus cfr. poricinctus & 8 & 0 & 0.04 & 3.7 \\
\hline Minibiotus cfr. scopulus & 6 & 0 & 0.03 & 5.6 \\
\hline Diphascon scoticum Murray, 1905 & 5 & 0 & 0.03 & 2.8 \\
\hline Minibiotus intermedius (Plate, 1888) & 5 & 0 & 0.03 & 3.7 \\
\hline Diphascon bullatum Murray, 1905 & 1 & 0 & 0.01 & 0.9 \\
\hline Diphascon higginsi Binda, 1971 & 1 & 0 & 0.01 & 0.9 \\
\hline Mesocrista spitsbergense (Richters, 1903) & 1 & 0 & 0.01 & 0.9 \\
\hline Sum & 19909 & 979 & 100 & \\
\hline
\end{tabular}

cover. Therefore, the period in which tardigrades were inactive by extreme low temperatures (e.g. December / January 2002) was relatively short and at most dates in the winter tardigrades were active. Mean rainfall varied considerably and was on average $1588 \mathrm{~mm}$ per year (Fig. 2). However, comparing total rainfall (in $\mathrm{mm}$ ) per year with the mean for many years, a clear drop was seen in 2003, particularly in 2004 (not pictured). Atmospheric humidity varied between $66 \%$ and $91 \%$ over the months and showed a significant positive cor- relation (Spearman rank correlation test, $p<0.01$ ) with rainfall (Fig. 2).

\subsection{Number, abundance, dominance, and frequency of species}

Tardigrades were found in $100 \%$ of the moss samples. A total of 19,909 eutardigrades and 979 free eggs and exuviae containing eggs were extracted belonging to 24 species (Tab. 1). Eggs and exuviae were not included in the calculations of ecological parameters; 


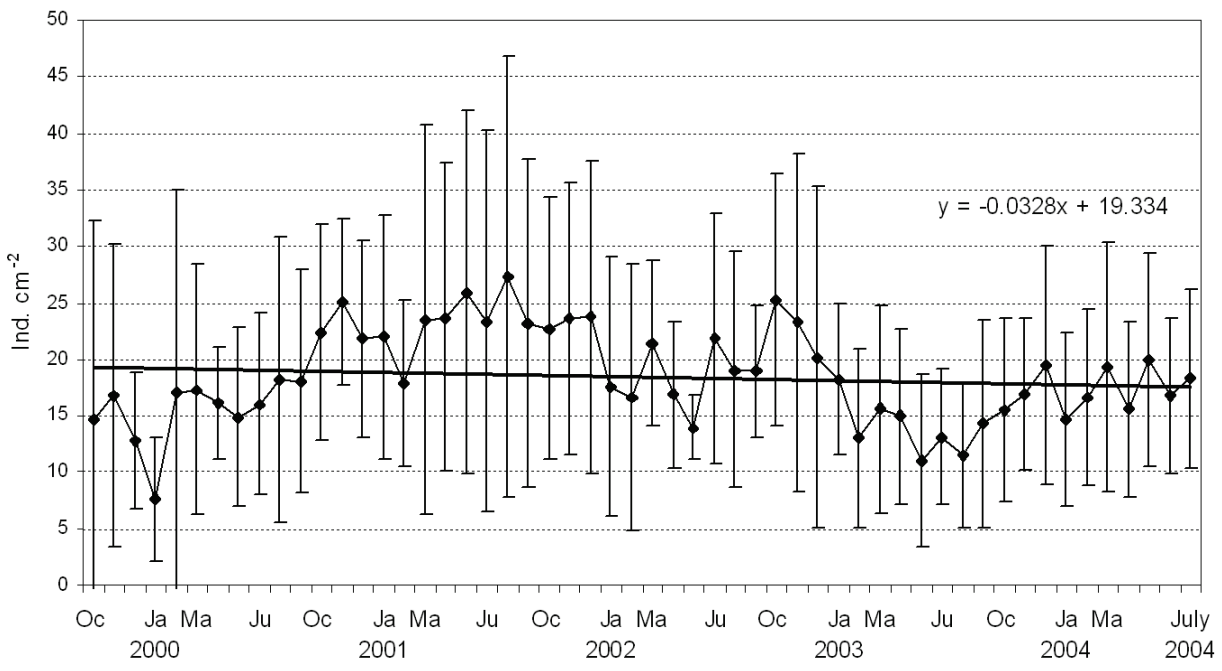

Fig. 3. Monthly fluctuations of the number of tardigrades (ind. $\mathrm{cm}^{-2}$ ), standard deviation and regression line during the period of investigation $(\mathrm{n}=54)$.

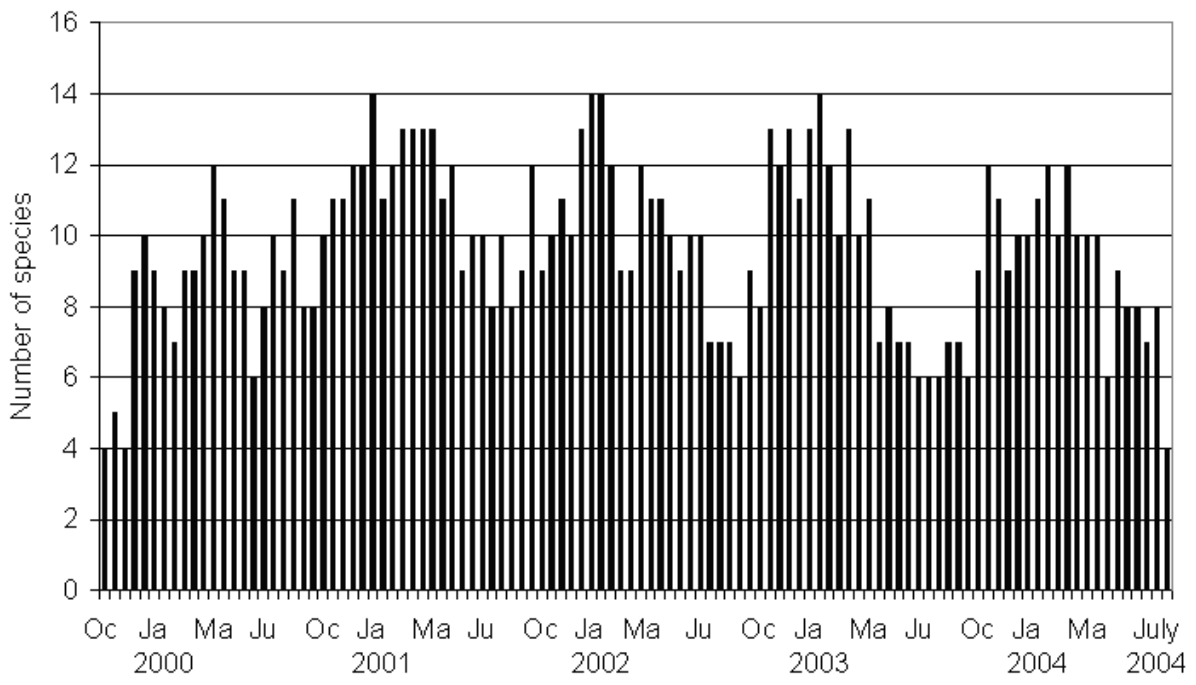

Fig. 4. Fortnightly fluctuation of the absolute number of species during the period of investigation. Species number is higher in autumn and winter $(\mathrm{n}=108)$.

sample surveys showed that they would not have significantly changed the results. Heterotardigrades were not found at the study site.

Abundances ranged from 58 to 320 individuals per sample (5.5-30.2 ind $\left.\mathrm{cm}^{-2} ; \mathrm{n}=108\right)$. Dominances varied considerably and ranged from 0.01 to $56 \%$. Ten species were found sporadically $(<0.32 \%)$, four species were subrecedent $(0.32-0.99 \%)$, seven were recedent $(1-3.1 \%)$, two species were dominant $(10-31.9 \%)$ and one species was eudominant (32-100\%; classification after Engelmann 1978). The same holds for the frequency ranging from $0.09 \%$, to $100 \%$ (Tab. 1). Three species (Macrobiotus hufelandi, Macrobiotus richtersi and Diphascon pingue) were found in each month and in each sample showed the highest dominances and frequencies.

\subsection{Temporal variation of the community}

The entire community indicated some fluctuation over the years (Fig. 3), but did not decrease significantly $(F=0.788 ; p=0.3788)$. This held also for the number of species (Fig. 4) that varied from 4 (October, November 1999) to 14 (December 2000, 2001, January 2001, 2002, 2003). We found 11 species in 1999 (3 months), 19 species in 2000 and 2001 (12 months), 16 species in 2002 (12 months), 17 species in 2003 (12 


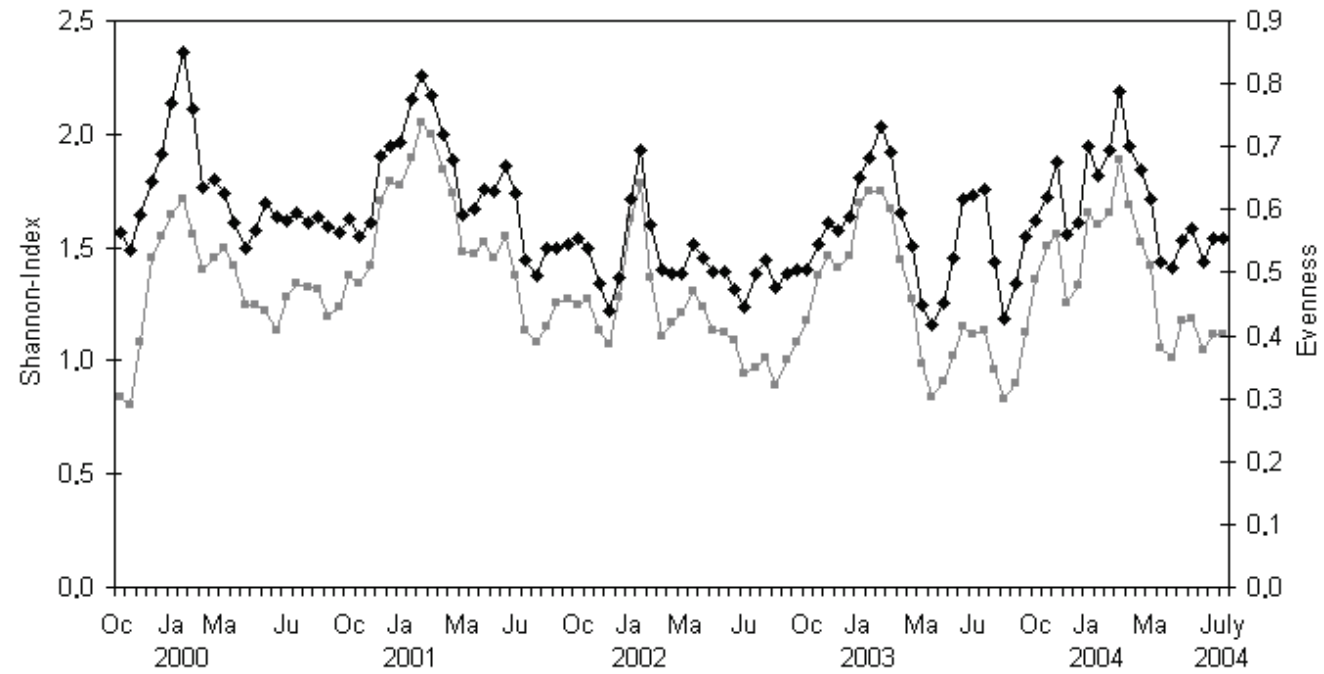

Fig. 5. Fortnightly fluctuation of the Shannon-Wiener diversity index (squares) and Evenness (rhombi) of the tardigrade community during the investigation period $(\mathrm{n}=108)$.

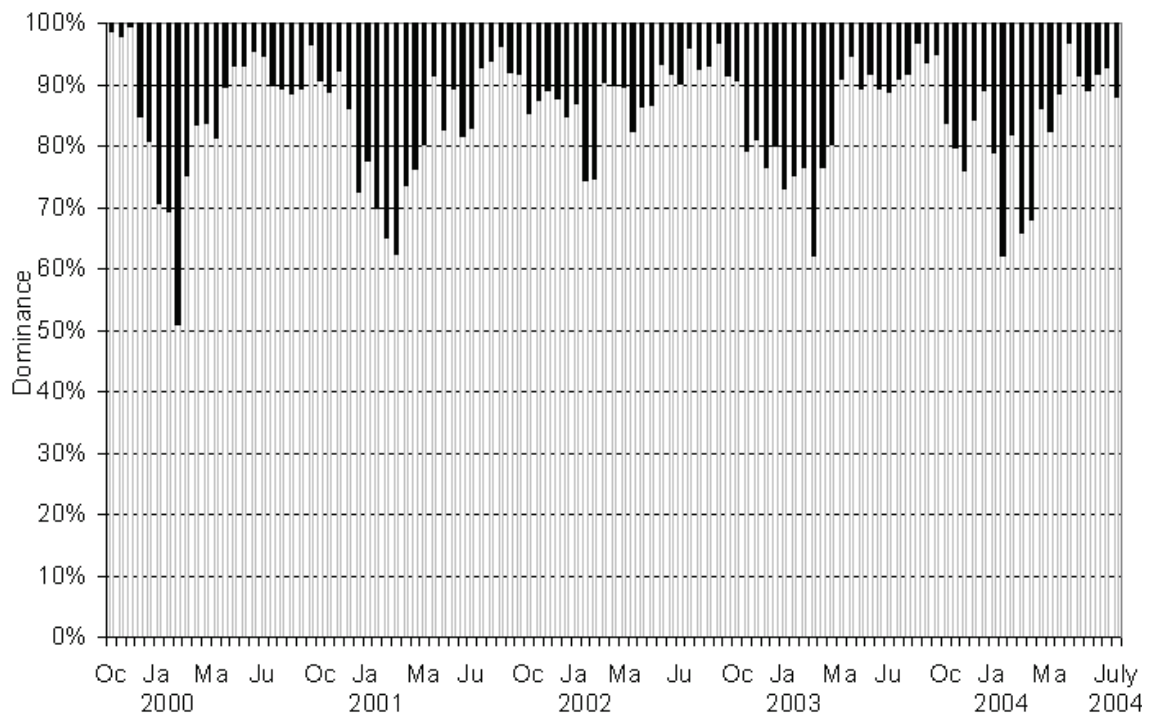

Fig. 6. Dominance of the three most frequent and dominant species (white columns) versus the remaining species (black columns) $(\mathrm{n}=108)$.

months) and 20 species in 2004 (7 months). Generally, the same 14 species were found every year except 1999 , when sampling covered only three months (Tab. 1). Some species were found only once, some only in a single year, and some intermittently.

Accordingly, the diversity index (Shannon-Wiener index) showed significant fluctuations with the highest values in wintertime; it was paralleled by evenness (Fig. 5). The dominances of $M$. hufelandi, M. richtersi, and $D$. pingue revealed seasonal fluctuations at a high level that appear exactly opposite to the remaining species (Fig. 6). Among the remaining species the most important were Diphascon rugosum, Hypsibius dujardini, and Hypsibius cfr. convergens. These species were responsible for relative high dominances and the high
Shannon-Wiener index and evenness in wintertime. We did not see any noticeable change in species composition, decrease in abundance, or other changes of the tardigrade community after mowing.

\subsection{Temporal variation of selected populations}

For the above-mentioned six species, figures 7a-e show fluctuation of the mean number of individuals per $\mathrm{cm}^{2}$ over the years.

In M. hufelandi (Fig. 7a) lowest mean numbers were found in wintertime. A slight but not significant increase of the population may be stated throughout the study period $(F=0.1788 ; p=0.6741)$. Also in $M$. richtersi (Fig. 7b) lowest mean numbers were recorded in 

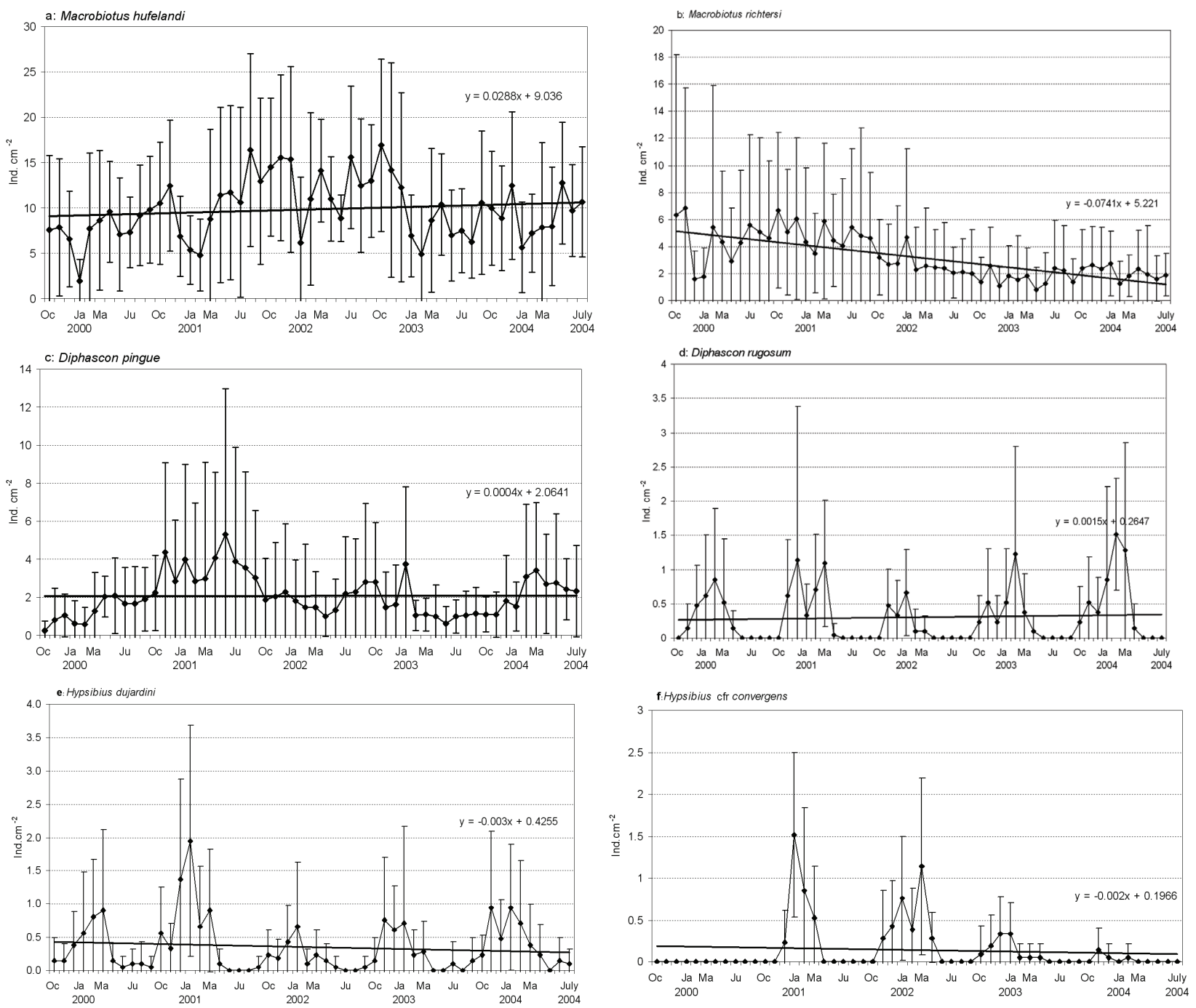

Fig. 7. Monthly fluctuation of mean numbers (ind. $\left.\mathrm{cm}^{-2}\right)$, standard deviation and regression line of six selected species $(\mathrm{n}=54) . \mathbf{a}$ Macrobiotus hufelandi. b: Macrobiotus richtersi. c: Diphascon pingue. d: Diphascon rugosum. e: Hypsibius dujardini. f: Hypsibius cfr. convergens.

wintertime except April 2003. Comparing the years 1999 to 2002 and 2002 to 2004, a considerable decline of the population is suggested leading to a highly significant decrease of the population during the study period $(F=53.043 ; p=>0.0001)$. Mean number of individuals of $D$. pingue (Fig. 7c) were very low in some months, but decrease could not attributed to a definite season. Over the years the abundance changed but not significantly $(F=0.001764 ; p=0.9667)$.

A remarkable seasonal cycle was apparent in three species. Diphascon rugosum (Fig. 7d) was collected only from October to April. The period when animals could be found varied from five to seven months. Over the years there was no significant decline of the population $(F=0.1788 ; p=0.6741)$. Hypsibius dujardini (Fig. $7 \mathrm{e})$ was collected in sufficient numbers especially from October to March. The period varied from two to six months. No significant decline was seen over the years
$(F=0.7439 ; p=0.3924)$. Hypsibius cfr. convergens (Fig. 7f) was not found in 1999/2000 and was shown to be present in the following years from December to March in sufficient numbers. In 2003/2004 only a few individuals were extracted. The population did not decline significantly $(F=0.5325 ; p=0.4688)$.

\subsection{Correlations with rainfall and temperature}

Variation of the Shannon-Wiener diversity index and the air temperature are mutually dependent, i.e. low temperatures cause a high diversity, high temperatures a low diversity (Fig. 8).

Table 2 shows the correlation matrix for the mean number of 10 tardigrade species per $\mathrm{cm}^{2}$ reaching dominances $>1$. Abundance of several species correlated significantly with rainfall 10,20 , and 30 days or at least 20 and 30 days after sampling. Correlation was positive 


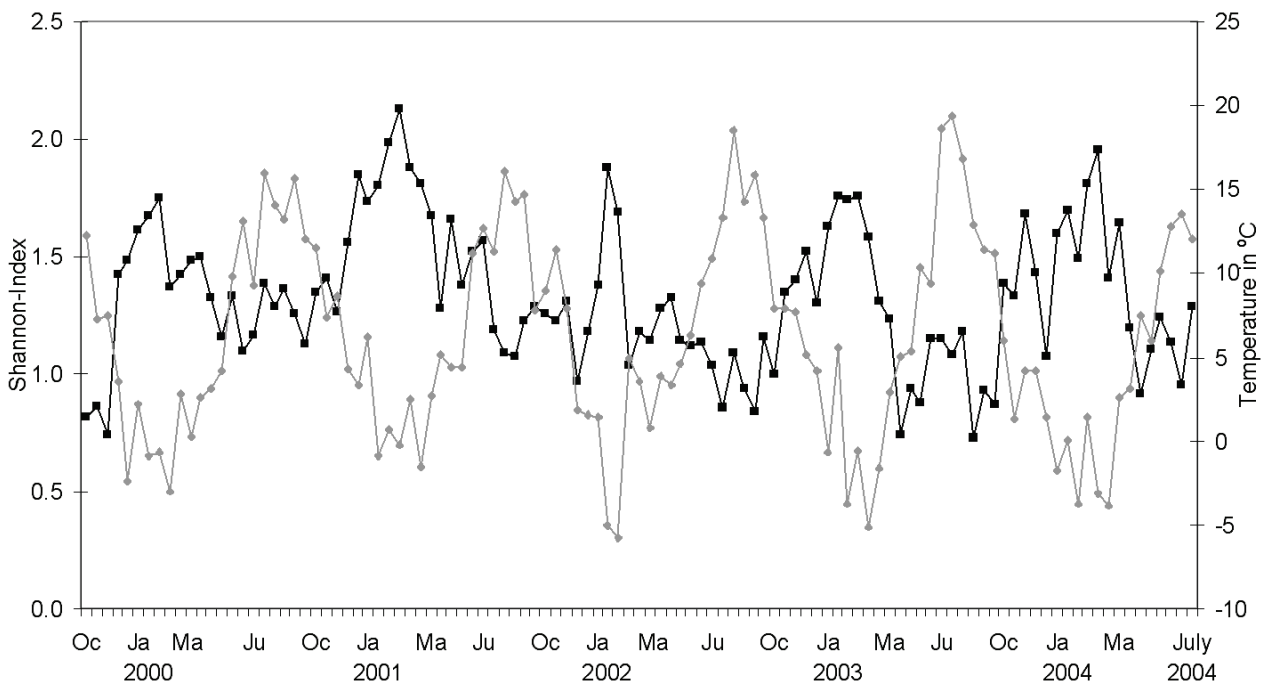

Fig. 8. Fortnightly fluctuation of the Shannon-Wiener diversity index (squares, left) and air temperature (rhombi, right) during the investigation period. Note the opposite course of the two curves $(n=108)$.

Tab. 2. Correlation matrix for the mean number of 10 selected tardigrade species and total number of individuals per $\mathrm{cm}^{2} . *: p<0.05 ; * *: p<0.01$. For further explanation see text.

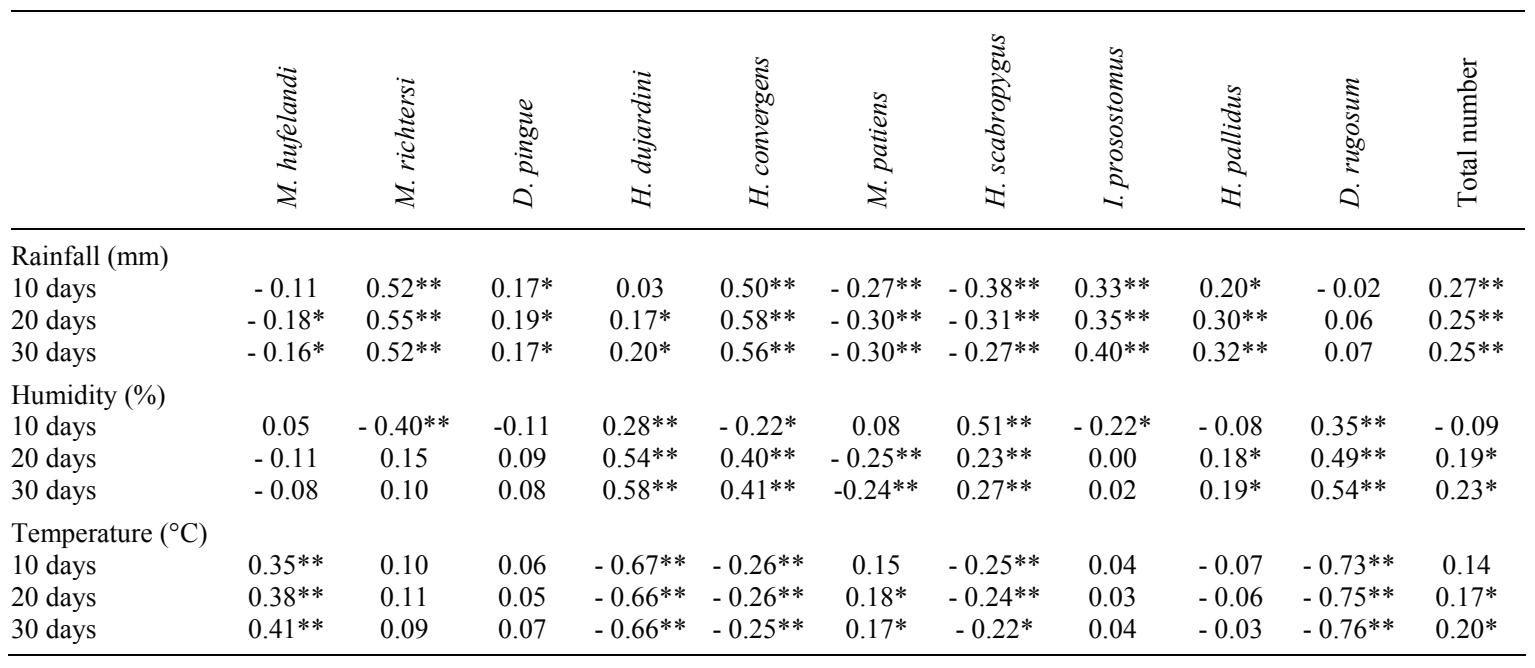

(M. richtersi, D. pingue, H. dujardini, Hypsibius convergens, Isohypsibius prosostomus, Hypsibius pallidus), negative (M. hufelandi, Macrobiotus patiens, Hypsibius scabropygus), or indifferent (D. rugosum). Abundance of several species correlated significantly with humidity 10,20 , and 30 days or at least 20 and 30 days after sampling. Correlation was positive (H. dujardini, H. convergens with a change to a negative correlation 10 days before sampling (H. scabropygus, H. pallidus, D. rugosum), negative (M. hufelandi, M. patiens, and M. richtersi in part), or indifferent (D. pingue, I. prosostomus). Abundance of several species correlated significantly with temperature 10, 20 and 30 days or at least 20 and
30 days after sampling. Correlation was positive ( $M$. hufelandi, $M$. patiens), negative (H. dujardini, H. convergens, $H$. scabropygus, $H$. pallidus, D. rugosum) or indifferent (M. richtersi, D. pingue, I. prosostomus).

\section{DISCUSSION}

The present study is the first following the population dynamics of tardigrades over more than 4 years at a limited and uniform study site overgrown by a single moss species. These conditions allow for assuming a set of microhabitats identical to a large degree and similarly affected by the local climate (which is generally char- 
acterized by a relatively high atmospheric humidity, steady rainfall, and relatively low average temperatures; see Schuster 2003). Here we showed a notable richness of largely ubiquitous eutardigrade species, dominated by Macrobiotus hufelandi, Macrobiotus richtersi, and Diphascon pingue. Variation of species composition and the absence of species throughout certain months obviously reflect a regular pattern rather than inconsistent or unstable associations of tardigrades. This suggestion is supported by the fact that 14 species (with different variation patterns) were always present throughout the period of investigation and that diversity and evenness regularly parallel the fluctuations and showed no remarkable drop during the investigation period. The moist and cold winters with only few warming sunshine hours favour development of more hygrophilous and even cold-stenothermic species, the relatively dry summers rich in sunshine summers, the relative increase of euryhygric species.

\subsection{Quantitative sampling of tardigrades in the moss Rhytidiadelphus squarrosus}

Reliable quantitative data of the density of tardigrades (and other organisms) in moss cushions are difficult to obtain in practice and from literature as 1) tardigrades show a patchy distribution within a moss cushion (e.g., Hallas 1975, see Fig. 2 in his article) not fully understood yet, but probably due to microhabitat differences, and 2) density is either expressed as individuals per area (Morgan 1977; Jennings 1979; Ito 1999) or per dry weight of the substrate (Morgan 1977; Grabowski 1995; Jönsson 2003). Authors usually do not give reasons for that. The first problem may be relative to the number of samples.

In the present study, due to the homogeneity and continuity of the substrate, we could randomly collect several homogeneous samples (12 samples per month). These numbers gave reliable data over years despite high variation and standard deviations of the mean number of tardigrades per $\mathrm{cm}^{2}$. The second problem largely depends on the moss species, i.e. the length of the single moss plants and the proportions and qualities of the three moss layers, mainly of the dense bottom of the rhizoid and soil layer (c-layer) (Overgaard 1948; Hallas 1975). The c-layer of $R$. squarrosus was small at our study site and density expressed per area and weight fairly corresponded in our samples (not shown).

\subsection{Rhytidiadelphus squarrous as habitat for tardigrades}

Mosses in general are considered as potent habitats for tardigrades, but it is a matter of debate, whether a relationship exists between tardigrade species and moss species. Specific associations between moss characteristics and tardigrades have been suggested (Hallas 1978; Hofmann 1987; Grabowski 1995) as well as a correlation between species diversity, habitat preferences and the process of aging and / or biodegradation of a moss restricting tardigrade species to a specific range of microhabitats (Hallas 1978). The presence of microhabitats suitable for certain species (and their forage organisms) depends not only on mesoclimatic regimes, but also more directly on the structure of the respective moss, i.e. its ability to hold water and other moss-related factors (e.g., Overgaard 1948; Wright 1991; Grabowski 1995; Greven \& Schüttler 2001).

The moss, $R$. squarrosus, at our study site indicates acid soils (pH 5-6; Düll 1991) and is the most common "weed" in lawns that dry out occasionally (Frahm 2001). This moss has a considerable hydration capacity storing water up to ten times of its dry weight (Grabowski 1995). The surface of the leaves is well structured and the ratio between the three layers of a single shoot from our study site was approximately 3:3:1 (Schuster \& Greven in preparation). When fully hydrated, $R$. squarrosus is covered by a continuous water film. Numerous water-filled axils provide sufficient space for locomotion and foraging provided that the interstitial water and their interconnected water pockets allow such activities (Greven \& Schüttler 2001).

Terrestrial mosses house a varying number of tardigrades and density estimations extend to 823 specimens per $\mathrm{g}$ dry weight and 228.7 per $\mathrm{cm}^{2}$ (Bryum argenteum (Hedwig, 1801); Morgan 1977) and even 660 tardigrades per 0.0286 g (i.e., 22000 animals $\mathrm{g}^{-1}$; Marcus 1929). July sampling from a coniferous forest stand in Sweden, the moss Rhytidiadelphus loreus (Hedwig) Warnstorf, 1906, Jönsson (2003) yielded on average of $161.2 \pm 152.3$ tardigrades per $\mathrm{g}$ dry weight of only two species (M. hufelandi and D. pingue). In our July samples (July 2000 - 2004) we collected a mean number of specimens ranging from $106.5 \pm 18.3$ to $276.5 \pm 15.5$ ind. $\mathrm{g}^{-1}$. The considerable high species richness at our study site and their cyclical fluctuations (see below) implies that apart from the properties of the moss plant itself, other factors (e.g. the environment in which the moss grows as exposure, insulation, ambient relative humidity, temperature, amount of rainfall) are responsible for development and maintenance of the large populations of tardigrades.

In the few studies on tardigrades of grassland soils (Ramazzotti 1959; Fleeger \& Hummon 1975; Manicardi \& Bertolani 1987; Bertolani \& Rebecchi 1996) species number do not reach the number shown in the herein examined lawn. In no case was the possible effect of mowing on the tardigrade community studied. Mowing may change the microclimate enhancing desiccation and, thus, may favour more desiccation-tolerant species and even may cause lower diversity and abundance. However, we did not recognize any drop or other noticeable changes of the tardigrade community after frequent mowing. Surely, intactness of the moss layer after this procedure (see above) the conditions (shaded, relative low light levels) at the study site and the 
regional climate (high humidity and moderate temperatures) alleviates the possible impact of mowing. Interestingly, Jönsson (2003) could not demonstrate a significant difference in tardigrade density between a spruce/pine forest (16 species) and a clear-cut site (11 species).

\subsection{Ecological characterisation of selected tardigrades species, their correlations with rainfall, temperature and humidity, and temporal changes}

The majority of the identified tardigrade species are common, widespread, and classified as cosmopolitan, subcosmopolitan, or holarctic (Dastych 1988; McInnes 1994) and tychoalpine, i.e. euryzonal and mesocalciphilous (classification after Dastych 1987, 1988). For a more detailed classification of tardigrades recorded from the Black Forest (Germany) see Schuster (2003).

Notable is the absence of heterotardigrades at our study site. Echiniscus testudo, a heterotardigrade species with eurytopic tendencies without clear xeric affinities (Wright 1991), was regularly collected nearby in sunexposed habitats (mosses on the roof and between tiles of a terrace) not colonized by $R$. squarrosus. We attribute the absence of xerophilous and eucalciphilous Echiniscidae (Dastych 1987, 1988; Wright 1991) to the moisture regime and the relatively low $\mathrm{pH}$ of the moss carpet.

Knowledge of the microclimate in a moss cushion should significantly contribute understanding processes affecting population dynamics of tardigrades and characterizing species ecologically, which measurements, however, encounter considerable difficulties (Schuster et al., in preparation). Some indirect evidence is given by correlations with the number of tardigrades and mesoclimatic variables (Franceschi et al. 1963; Morgan 1977; Wright 1991; Grabowski 1995). From these studies two consider a single moss species or mosses at a limited study site (Franceschi et al. 1963; Morgan 1977). Positive and negative correlations, e.g. of humidity and rainfall, with the abundance of a given species reported in these studies obviously depended on the duration of the sampling period and on specific regional climatic effects (Franceschi et al. 1963; Morgan 1977). The highly significant positive correlation between the total number of tardigrades and the rainfall shown herein reflects simply the strong dependence of the tardigrade species living in the moss $R$. squarrous on moisture and humidity, which in turn is influenced by temperature. These variables have a strong influence on the Shannon-Wiener diversity index.

At the species level this correlation is qualified to some extent. Macrobiotus hufelandi, with a broad ecological valence and eurytopic capacity, classified as euryhygric-hygrophilous (Grabowski 1995) or hygrophilous (Wright 1991), is the only species that benefited from the temperatures, whereas the other species did not or reacted indifferently. Rainfall and humidity had no positive effect on $M$. hufelandi. In our study site with a mean rainfall already relatively high, moisture may be of secondary importance for this species. Strikingly, the xerophilous (Grabowski 1995) or eurytopic (Wright 1991) M. richtersi appeared to depend closer on the moisture regime at our study site like the euryhygric (Grabowski 1995) or hygrophilous (Dastych 1988) D. pingue. Hypsibius dujardini, known also from water bodies (Marcus 1929), was classified as hygrophilous by several authors (Ramazzotti \& Maucci 1983; Dastych 1988; Wright 1991), and even xerophilous by Grabowski (1995). Correlations with mesoclimatic factors of this species and of $H$. convergens support hygrophily and indicate preference of relative low temperatures. Macrobiotus patiens might prefer drier habitats (negative correlation with rainfall, in part with humidity, and a positive correlation with temperature). Hypsibius scabropygus, Isohypsibius prosostomus (see also Grabowski 1995) and Hypsibius pallidus may be euryhygrous and Diphascon rugosum (Dastych 1988) may be hygrophilous.

Macrobiotus hufelandi, M. richtersi and D. pingue occurred consistently in all months (frequency 100\%), but abundances show an annual cycle with a basically unimodal pattern. In $M$. hufelandi we observed a minimum in wintertime and an increase in spring with maxima until fall. Similar results were obtained by Morgan (1977) for M. hufelandi (and E. testudo) in roof mosses in one of his study sites and the increase in spring was reported by Franceschi et al. (1963). However, in two other study sites Morgan (1977) did not found such a temporal variation in $M$. hufelandi. For varying fluctuations of tardigrade population over a longer time also refer to Jennings (1979).

Fluctuations of $D$. pingue and $M$. richtersi are less regular, but compared to the preceding and following months in most cases relative low mean numbers were seen in winter. In $M$. richtersi the pattern was additionally obscured by a significant gradual decline of the population, namely in the second half of the study period. Drop of tardigrade populations have been attributed to climatic factors as suggested for the temporal variation in tardigrade numbers described herein and by other authors. For example, desiccation influences the population of Hypsibius convergens (Marcus 1927); trophic overlapping and predation by arthropods influence various species (Hyvönen \& Person 1996); food availability seems to influence $H$. convergens (Marcus 1927) and Macrobiotus harmsworthi Murray, 1907 (Hallas \& Yeates 1972). Reasons for the decline of $M$. richtersi at our study site are not clear. Wright (1991) described negative associations between $M$. hufelandi, M. richtersi and Hypsibius prosostomus and suggested competitive exclusion due to trophic overlap and ecological resemblances. However, $M$. richtersi is a largely carnivorous species, whereas the other two dominating 
species, M. hufelandi and D. pingue, are considered omnivorous or algae-feeders.

There are only a few hints of a strictly seasonal presence of tardigrade species in literature. Dastych (1988) found Diphascon rugosum in Poland between October and April only. Depending on the altitude Guidetti et al. (1999) and Guidetti \& Bertolani (2001) reported on species found exclusively in autumn and winter such as $H$. convergens, or species that dominated in winter and spring such as Isohypsibius sattleri Richters, 1909 and others, suggesting "specific ecological requirements" not further specified. We showed herein clear cyclic variations of D. rugosum, Hypsibius dujardini, and Hypsibius cfr. convergens in a nearly identical pattern every year over several years. The three species were found in reliable numbers in fall to early spring only. In the rest of the years they were not found or were collected in low numbers. Absence in summer may reflect real absence or extreme rareness. How and where animals may survive unfavourable months, perhaps as cysts in the moist soil, remains to be studied. Ecological needs of these species are unknown. However, regarding the preference for wintertime and the above-mentioned correlations with temperature, we tentatively classify at least $D$. rugosum as cold-stenothermic and $H$. cfr. convergens as oligostenothermic.

\section{ACKNOWLEDGMENTS}

We acknowledge the invaluable help of Dr. $\mathrm{H}$. Dastych, Hamburg, who initiated us into the mysteries of tardigrade identification and helped with "difficult" species, and the statistical advice of Dr. Th. Eltz, Düsseldorf.

\section{REFERENCES}

Backhaus, K., B. Erichson, W. Plinke \& R. Weiber. 1966. Multivariante Analysemethoden. Springer Verlag, Berlin: $230 \mathrm{pp}$.

Bertolani, R. \& L. Rebecchi. 1993. A revision of the Macrobiotus hufelandi group (Tardigrada, Macrobiotidae), with some observations on the taxonomic characters of eutardigrades. Zool. Scripta, 22: 127-152.

Bertolani, R. \& L. Rebecchi. 1996. The tardigrades of Emilia (Italy). II. Monte Rondinaio. A multihabitat study on a high altitude valley of the northern Apeninnes. Zool. J. Linn. Soc., 116: 3-12.

Dastych, H. 1987. Altitudinal distribution of Tardigrada in Poland. In: R. Bertolani (Ed.), Biology of Tardigrades. Selected Symposia and Monographs U.Z.I., 1. Mucchi Editore, Modena, Italy: 169-214.

Dastych, H. 1988. The Tardigrada of Poland. Monografie Fauny Polski, 16. Panstwowe Wydawnictwo Naukow, Warszawa: 1-255.

Düll, R. 1991. Zeigerwerte von Laub- und Lebermoosen. Scripta Geobot., 18: 175-215.

Engelmann, H.-D. 1978. Zur Dominanzklassifizierung von Bodenarthropoden. Pedobiologia, 18: 378-380.

Fleeger, J.W. \& W.D. Hummon. 1975. Distribution and abundance of soil Tardigrada in cultivated and uncultivated plots of an old field pasture. Mem. Ist. ital. Idrobiol., 32 Suppl.: 93-112.
Frahm, J.-P. 2001. Biologie der Moose. Spektrum Akademischer Verlag, Heidelberg, Berlin: 370 pp.

Franseschi, T., M.L. Loi, \& R. Pierantoni. 1963. Risultati di una prima indagine ecologica condotta su popolazioni di Tardigradi. Boll. Mus. Ist. Univ. Genova, 32: 69-93.

Grabowski, B. 1995. Ökologische Untersuchungen an moosbewohnenden Bärtierchen (Tardigrada) mit einem Bericht über drei neue Arten für Deutschland. Acta Biol. Benrodis, 7: 77-98.

Greven, H. 1980. Tardigrada. A. Ziemsen Verlag, Wittenberg Lutherstadt: $100 \mathrm{pp}$.

Greven, H. \& L. Schüttler. 2001. How to crawl and dehydrate on moss. Zool. Anz., 240: 341-344.

Guidetti, R. \& R. Bertolani. 2001. The tardigrades of Emilia (Italy). III. Piane di Mocogno (Northern Apennines). Zool. Anz., 240: 377-383.

Guidetti, R., R. Bertolani \& D. Nelson. 1999. Ecological and faunistic studies in tardigrades in leaf litter of beech forests. Zool. Anz., 238: 215-223.

Hallas, T.E. 1975. Interstitial water and Tardigrada in a moss cushion. Ann. Zool. Fenn., 12: 255-259.

Hallas, T.E. 1978. Habitat preference in terrestrial Tardigrades. Ann. Zool. Fen., 15: 66-68.

Hallas, T.E. \& G.W. Yeates. 1972. Tardigrada of the soil and litter of a Danish beech forest. Pedobiologia, 12: 287-304.

Hofmann, I. 1987. Habitat preference of the most frequent moss-living Tardigrada in the area of Giessen (Hessen). In: R. Bertolani (Ed.), Biology of Tardigrades. Selected Symposia and Monographs U.Z.I., 1. Mucchi Editore, Modena, Italy: 211-216.

Hyvönen, R. \& T. Persson. 1996. Effects of fungivorous and predatory arthropods on nematodes and tardigrades in microcosms with coniferous soil. Biol. Fertil. Soils, 21: 121127.

Ito, M. 1999. Ecological distribution, abundance and habitat preference of terrestrial tardigrades in various forests on the Northern slope of Mt. Fuji, Central Japan. Zool. Anz., 238: $225-234$

Jennings, P.G. 1979. The Signy island terrestrial reference sites: X. Population dynamics of Tardigrada and Rotifera. Br. Antarct. Surv. Bull., 47: 89-105.

Jönsson, K.I. 2003. Population density and species composition of moss-living tardigrades in a boreo-nemoral forest. Ecography, 26: 356-364.

Marcus, E. 1927. Zur Oekologie und Physiologie der Tardigraden. Zool. Jb. Phys., 44: 323-370.

Marcus, E. 1929. Tardigrada. In: H.G. Bronn (Ed.), Klassen und Ordnungen des Tierreichs 5, Abtlg IV, Buch 3. Akademische Verlagsgesellschaft, Leipzig: 1-530.

Manicardi, G.C. \& R. Bertolani.1987. First contribution to the knowledge of alpine grassland tardigrades. In: R. Bertolani (Ed.), Biology of Tardigrades. Selected Symposia and Monographs U.Z.I., 1. Mucchi Editore, Modena, Italy: 177-185.

McInnes, S.J. 1994. Zoogeographic distribution of terrestrial/freshwater tardigrades from current literature. J. Nat. Hist., 28: 257-352.

Morgan, C.I. 1977. Population dynamics of two species of Tardigrada, Macrobiotus hufelandii (Schultze) and Echiniscus (Echiniscus) testudo (Doyère), in roof moss from Swansea. J. Anim. Ecol., 46: 236-279.

Nelson, D.R. 1975. Ecological distribution of tardigrades on Roan Mountain, Tennessee-North Carolina. Mem. Ist. ital. Idrobiol., 32 Suppl.: 225-276.

Overgaard, C. 1948: Studies on the soil microfauna. I. The moss inhabiting nematodes and rotifers. Naturvidensk. Skr. Laerde. Selk. Skr. Arhus, 1: 1-98.

Pilato, G. \& M.G. Binda. 1997. A comparison of Diphascon (D.) alpinum Murray, 1906, D. (D.) chilenense Plate, 1889 and D. (D.) pingue Marcus, 1936 (Tardigrada), and description of a new species. Zool. Anz,. 236: 181-185. 
Pilato, G. \& M.G. Binda. 1999. Three new species of Diphascon of the pingue group (Eutardigrada, Hypsibiidae) from Antarctica. Polar Biol., 21: 335-342.

Ramazzotti, G. 1959. Tardigradi in terreni prativi. Atti Soc. Ital. Nat., Milano, 98: 199-210.

Ramazzotti, G., \& W. Maucci. 1983. Il Phylum Tardigrada. Terza edizione riveduta e aggiornata. Mem. Ist. ital. Idrobiol., 41: 1-1012.
Schuster, R. 2003. Faunistische und ökologische Untersuchungen an Tardigraden des Schwarzwalds (Deutschland). Acta Biol. Benrodis, 12: 147-192.

Steiner, W.A. 1994. The influence of air pollution on mossdwelling animals. 4- Seasonal and long-term fluctuations of rotifer, nematode, and tardigrade populations. Rev. Suisse Zool., 101: 1017-1031.

Wright, J.C. 1991. The significance of four xeric parameters in the ecology of terrestrial Tardigrada. J. Zool. Lond., 224: 59-77. 